\title{
MELACAK PERAN AGAMA DALAM RUANG PUBLIK
}

\author{
Redemptus B. Gora'
}

\begin{abstract}
Abstrak
Pemikiran Jurgen Habermas tentang masyarakat postsekular harus dimengerti juga dalam kaitannya dengan kebangkitan agama. Dalam masyarakat sekular, lewat proses modernisasi, agama didomestifikasi. Kini dalam zaman postsekular agama bukannya lenyap, sebaliknya justeru menunjukkan potensi semantiknya. Melihat peristiwa itu, Jurgen Habermas meyakini bahwa peran agama dalam ruang publik suatu negara hukum demokratis perlu diperhitungkan. Agama tidak cukup dipandang sebagai artefak kebudayaan yang usang. Penulis berusaha menguraikan bagaimana Habermas menimbang eksistensi dan peran agama itu dalam ruang publik.
\end{abstract}

Kata kunci: sekular, postsekular, agama, ruang public

\section{Pengantar}

Di abad ke-19 dan ke-20, tesis agama akan lenyap dari ruang publik banyak didukung oleh pemikir di Barat. Lewat proses modernisasi, agama dengan sendirinya akan redup kemudian hilang dari peredarannya, lantas yang tersisa hanyalah artefak kebudayaan yang usang. Agama, meminjam istilah Hardiman, akan mengalami domestifikasi. Tesis seperti itu dapat kita lihat dalam pemikiran Karl Marx, Max Weber, Auguste Comte, dan Emile Durkheim. Tidak hanya di kalangan sosiolog dunia, bahkan Habermas, filsuf Jerman kontemporer, di masa mudanya juga pernah menganut tesis yang sama. Sejarah modernisasi yang ditandai oleh rasionalisasi mengantar agama pada ruang privat. Ia melihat sengatan modernitas dapat mengatasi agama. Pemikiran Habermas yang demikian termaktub dalam karya

1 Redemptus B. Gora, mahasiswa semester VIII di Sekolah Tinggi Filsafat Driyarkara, Jakarta 
mudanya, khususnya Theorie de Kommunikativen Handeln (Teori Tindakan Komunikatif).

Dalam karya itu ditunjukkan bagaimana peran agama, dengan proses sejarah yang panjang, akan digantikan oleh tindakan komunikatif serta konsensus-konsensusnya. Apabila pada masyarakat tradisional, seperti Gereja Abad Pertengahan di Eropa, menafsir dunia kehidupan (Lebenswelt) secara monopoli, dengan menggunakan dogmanya sebagai acuan, kini (modernisasi) terjadi proses rasionalisasi kehidupan masyarakat. Teologi abad pertengahan percaya bahwa sumber kebenaran itu ada dalam agama. Relasi agama dan negara memang tidak sungguh radikal, karena masih ada distansi antara yang profan dan sakral. Namun demikian, yang profan tidak memiliki otonomi di hadapan yang sakral. Secara ketat, masyarakat tradisional memandang kegiatan non-ritual juga dari segi dogmatis agama. ${ }^{2}$

Fungsi ekspresif serta integratif sosial yang selama ini dimainkan oleh praksis ritual keagamaan akan digantikan oleh tindakan komunikatif. Seiring dengan proses modernisasi, kekuasaan dari Yang Suci disublimasikan menjadi kekuasan yang mengikat dari klaim-klaim keabsahan yang senantiasa dapat dikritik. ${ }^{3}$ Namun demikian, konsep Habermas di usia senjanya tentang masyarakat postsekular sangatlah berguna untuk menilai ulang fungsi agama yang mengantongi aspirasi yang patut diperhitungkan. Berbagai tulisan Habermas yang disatukan dalam traktat Antara Agama dan Naturalisme, 2005 dan dalam diskusinya dengan para profesor dari Hochschule Fur Philosophie Munchen yang dikumpulkan dalam traktat Suatu Kesadaran tentang apa yang kurang, dia telah meninggalkan pandangan yang berat sebelah itu. ${ }^{4}$ Perubahan pandangannya atas eksistensi dan peran agama dapat kita lihat dalam ceramahnya tentang iman dan pengetahuan yang dipaparkannya dalam rangka penerimaan penghargaan dari perkumpulan penerbit-penerbit di Jerman..$^{5}$ Di sana Habermas melihat potensi agama yang dapat menjadi

2 F. Budi Hardiman, Habermas tentang Masyarakat Post-sekular (Jakata: tidak diterbitkan, 2017), hlm. 2

${ }^{3}$ A. Sunarko, "Ruang Publik dan Agama menurut Habermas" dalam Budi Hardiman (ed), Ruang Publik; Melacak "Partisipasi Demokratis" dari Polis sampai Cyberspace (Yogyakarta: Kanisius,2010), hlm. 220

${ }^{4}$ Gusti A.B. Menoh, Agama dalam Ruang Publik; Hubungan Antara Agama dan Negara dalam Masyarakat Postsekuler Menurut Jurgen Habermas (Yogyakarta: Kanisius, 2015), hlm. 3

${ }^{5}$ A. Sunarko, Teologi Kontekstual (Yogyakarta: Kanisius, 2016), hlm. 194 
partner dalam mengkritisi dan meluruskan perkembangan masyarakat modern yang kelihatannya salah arah. Oleh karena itu, selain melihat potensi semantik agama, perubahan pandangan Habermas juga berkaitan dengan penilaiannya yang makin skeptis atas modernitas. ${ }^{6}$ Meskipun skeptisnya itu tidak seradikal para filsuf Mazhab Frankfurt sebelumnya, seperti Adorno dan Horkheimer. ${ }^{7}$

Di dalam tulisan ini kami tidak akan menjelaskan sekularisasi sebagai domestifikasi agama, tetapi membatasi diri pada agama di zaman postsekular. Terminologi postsekular berarti tetap eksisnya agama di tengah masyarakat modern yang sekular. Apabila dalam masyarakat sekular agama diprivatkan atau didomestifikasi, kini dalam tatanan baru yang disebut postsekular, terjadi proses saling belajar antara masyarakat sekular dan warga agama. Dalam konteks abad modernlah hangatnya perbincangan tentang sekularisme, meskipun keduanya tidak identik. Tentu saja mereka yang disebut masyarakat postsekular itu telah mengalami sekularisasi terlebih dahulu. Setelah mengalami sekularisasi agama bukannya lenyap, tetapi menunjukkan potensi semantiknya dalam ruang publik. Melihat fenomena itu, Habermas tua yakin bahwa agama, dengan segala aspirasinya, perlu dipertimbangkan dalam suatu negara hukum demokratis. Tinjauan peran agama dalam ruang publik dalam tulisan ini hanya dilihat dari kacamata Jurgen Habermas.

\section{Agama sebagai Partner}

Seperti telah dijelaskan sebelumnya, di usia senjanya, Habermas mengubah perspektifnya tentang agama. Orang yang menggeluti pemikiran Habermas pasti sungguh merasakan perubahan itu. Perubahan pandangannya terhadap keberadaan dan peran agama itu bukanlah suatu transformasi dari agnostik menjadi seorang beriman saleh. Agama tidak bisa begitu saja dipenjara dalam ruang privat seperti peristiwa sekularisasi sebagai domestifikasi agama. Akan tetapi, di lain pihak Habermas tetap berpegang pada tradisi liberal yang meyakini "akal budi bersama umat manusia" sebagai dasar pemisahan Gereja dan negara dan dasar kekuasaan negara modern yang tidak tergantung lagi

${ }^{6}$ Ibid., hlm. 191

7 F. Budi Hardiman, Kritik Ideologi; Menyingkap Pertautan Pengetahuan dan Kepentingan Bersama Jurgen Habermas (Yogyakarta: Kanisius, 2009), hlm. 72 
pada legitimasi agama. ${ }^{8}$ Potensi semantik agama yang sangat berpengaruh tidak boleh dipandang sebelah mata. Agama perlu mengambil bagian dalam ruang publik untuk menyerukan gagasangagasan keagamaannya. Bagi Habermas, gerakan agama yang damai dengan susunan opininya perlu dipertimbangkan. Intervensi agama dalam ruang publik ini juga menuntut kesediaan dari masyarakat sekular untuk saling belajar. Warga sekular, dengan kacamata kosmopolitannya yang indiferen terhadap agama, perlu berkomunikasi dengan warga beriman. Dalam kasus sosial yang diakibatkan oleh bioetika misalnya, agama dapat mengemukakan pandangannya, sebagai sumber moral penuh makna. Berkat makna yang dimiliki agama, ia berfungsi menyediakan basis moral bagi diskursus publik dan dengan demikian sesungguhnya agama dapat memainkan peran penting dalam ruang publik. ${ }^{9}$

Agama bukan sekedar atribut sosial, seperti keanggotaan dalam sebuah partai atau kelompok profesi, yang dapat dengan cepat diganti oleh atribut sosial lain, melainkan sebuah 'comprehensive worldview'.10 Selain itu, suara hati warga agama - sesuatu yang bersumber dari iman religius - dapat menjadi kekuatan kritis terhadap kekuasaan tirani dan ketidakadilan sosial, sebagaimana dipraktekan dalam civil rights movement yang dipimpin oleh Pendeta Martin Luther King Jr. di Amerika Serikat. ${ }^{11}$ Sebagai penganut filsafat pasca-metafisik, Habermas melihat dua masalah besar dari modernitas yang tampaknya salah arah. Pertama, perkembangan dalam bioteknologi yang berujung pada instrumentalisasi manusia. Instrumentalisasi ini tentu berbahaya karena selain mengubah konsep kita tentang kemanusiaan, juga dapat saling mengobjekkan di antara manusia itu sendiri. Padahal dalam berelasi

8 F. Budi Hardiman, Demokrasi Deliberatif; Menimbang Negara Hukum dan Ruang Publik dalam Teori Diskursus Habermas (Yogyakarta: Kanisius, 2009), hlm. 158

9 Gusti A.B. Menoh, Agama Dalam Ruang Publik; Hubungan Antara Agama dan Negara dalam Masyarakat Postsekuler Menurut Jurgen Habermas (Yogyakarta: Kanisius, 2015), hlm. 103

10 F. Budi Hardiman, Demokrasi Deliberatif; Menimbang Negara Hukum dan Ruang Publik dalam Teori Diskursus Habermas (Yogyakarta: Kanisius, 2009), hlm. 161

11 Gusti A.B. Menoh, Agama Dalam Ruang Publik; Hubungan Antara Agama dan Negara dalam Masyarakat Postsekuler Menurut Jurgen Habermas (Yogyakarta: Kanisius, 2015), hlm. 19 
Redemptus B. Gora, Melacak Peran Agama dalam Ruang Publik

seharusnya ada komunikasi, bukannya eksploitasi yang menguntungkan sepihak. Berhadapan dengan kasus seperti itu, apakah warga sekular mampu, dengan kecanggihan rasionya, memiliki dalam dirinya sendiri kemampuan yang cukup untuk melawan instrumentalisasi atas paham kita tentang manusia ini. ${ }^{12}$ Kedua, aksi-aksi teror yang dilakukan oleh kaum fundamentalis Islam pada 11 September 2001 dapat dimengerti sebagai reaksi kelompok tertentu atas modernitas.

Kedua persoalan di atas memantik pertanyaan terkait kemampuan rasio warga sekular. Apakah rasio warga sekular an sich mampu membendung proses modernisasi yang tampaknya salah arah itu? Apakah agama tidak dibutuhkan sebagai partner untuk mengatasinya? Apakah potensi spiritual dan dinamika masyarakat modern global an sich mampu membendung tendensi destruktif yang pertama-tama berupa hancurnya prinsip-prinsip normatifnya sendiri? ${ }^{13}$ Di mata Habermas, malapetaka yang diakibatkan modernitas berupa individualisme, disintegrasi sosial, benturan antar-peradaban, nuklir, penggunaan teknologi yang menghancurkan kehidupan umat manusia tidak dapat diselesaikan oleh modernitas itu sendiri. ${ }^{14}$ Buah perjalanan modernitas seperti itu tidak hanya membuat Habermas skeptis terhadap modernitas, tetapi juga memberi perhatian khusus terhadap agama. Buah keresahan intelektualnya adalah bahwa agama tidak cukup dipandang sebagai gejala sosial dalam sejarah manusia, apalagi artefak kebudayaan yang usang. Filsafat perlu menukik lebih dalam persoalan tersebut sebagai tantangan kognitif. Filsafat mau tidak mau perlu terbuka untuk membangun sikap saling belajar dari agama. Saling belajar tersebut "bukan hanya demi alasan-alasan fungsional, tetapi juga demi alasan substansial".

Keterbukaan untuk saling belajar antara kedua belah pihak itu sebenarnya bukan hal baru. Sejarah mencatat bahwa dalam perjumpaan kekristenan dengan filsafat Yunani, demikian Habermas, intervensi filsafat dalam menghasilkan teologi dogmatik cukup kuat dan helenisasi

12 A. Sunarko, Teologi Kontekstual (Yogyakarta: Kanisius, 2016), hlm. 196

13 A. Sunarko, "Dialog Teologis dengan Jurgen Habermas", dalam Paul Budi Kleden dan A. Sunarko (ed.), Dialektika Sekularisasi; Diskusi HabermasRatzinger dan Tanggapan (Maumere: Lamalera, 2010), hlm. 81

14 Gusti A.B. Menoh, Agama Dalam Ruang Publik; Hubungan Antara Agama dan Negara dalam Masyarakat Postsekuler Menurut Jurgen Habermas (Yogyakarta: Kanisius, 2015), hlm. 106 
kekristenan. Pemikir seperti Agustinus misalnya, seorang bapa Gereja abad pertengahan, ajarannya banyak dipengaruhi filsafat neoplatonis. Lebih dari itu, perjumpaan itu juga menyebabkan, bahwa gagasangagasan Kristiani diterima dalam sistem-sistem pemikiran filosofis. Sumbangsih itu tampak dalam konsep-konsep normatif, seperti tanggung jawab, otonomi dan pembenaran, sejarah dan memoria, emansipasi dan pemenuhan, individualitas dan sosialitas, dll. Konsepkonsep seperti itu memiliki asal usulnya dalam agama, yang kemudian ditransformasikan tanpa mengosongkan makna. ${ }^{15}$

Selain kedua masalah di atas, masih ada fenomena lain yang sebenarnya sangat menggelisahkan Habermas. Fenomena itu adalah menipisnya solidaritas di antara manusia seiring dengan berkembangnya modernisasi. Darurat solidaritas ini diakibatkan oleh merebaknya liberalisme di tengah masyarakat, sehingga manusia cenderung bersikap individualis. Dalam ruang publik, setiap individu hanya memikirkan kepentingannya sendiri. Setiap tindakan manusia didorong oleh kepentingan diri tanpa memikirkan orang lain. Eviden seperti itu meresahkan Habermas. Memang Habermas dikenal sebagai seorang filsuf kelas dunia yang memusatkan perhatiannya pada problem komunikasi intersubyektif. ${ }^{16}$ Orang menggunakan hak pribadinya sebagai senjata untuk saling melawan. Evidensi untuk satu kelunturan solidaritas para warga seperti ini menjadi nyata dalam konteks yang lebih besar, yakni dalam dinamika ekonomi dan masyarakat dunia yang secara politis tidak terkendalikan. ${ }^{17}$ Individualisme merupakan cacat tradisi liberalisme, karena ia sendiri tidak memiliki kekuatan, secara khusus moralitas, untuk mengatasinya. Saya tidak melihat kemungkinan, demikian Habermas, bagaimana dari konsep moral Kantian yang individualistis dapat dihasilkan pendasaran bagi kewajiban bersolider guna mencapai tujuan bersama. ${ }^{18}$ Artinya dari sudut moral, liberalisme tidak cukup canggih untuk membendung sikap

15 A. Sunarko, Teologi Kontekstual (Yogyakarta: Kanisius, 2016), hlm. 197

16 F. Budi Hardiman, Seni Memahami (Yogyakarta: Kanisius, 2015), hlm.

17 Jurgen Habermas, "Basis Prapolitis Sebuah Negara Hukum Demokratis", dalam Paul Kleden dan A. Sunarko (ed.), Dialektika Sekularisasi; Diskusi Habermas-Ratzinger dan Tanggapan (Maumere: Lamalera, 2010), hlm. 14

18 A. Sunarko, "Dialog Teologis dengan Jurgen Habermas", dalam Paul Budi Kleden dan A. Sunarko (ed.), Dialektika Sekularisasi; Diskusi HabermasRatzinger dan Tanggapan (Maumere: Lamalera, 2010), hlm. 85 
masyarakat warga yang individualis dan indiferen agar terjaminnya solidaritas sosial.

Berhadapan dengan situasi seperti itu, Habermas mencoba tidak hanya menjelaskan keterbatasan liberalisme, melainkan juga menunjukkan potensi agama untuk mengatasi hal seperti itu.

"Moral sekular dari asal usulnya tidak terintegrasi dalam suatu praksis bersama. sebaliknya, kesadaran religius secara hakiki terkait erat dengan praksis hidup yang kontinu dalam sebuah kelompok/persekutuan; dan dalam hal agama yang bersifat global, berarti terkait erat dengan ritus dari jemaat seluruh dunia. Berdasarkan komunitarisme yang universal ini, kesadaran religius masing-masing dapat-juga dalam hal pandangan moral-memberi dorongan yang lebih kuat untuk membangun solidaritas."19

Potensinya terletak pada kesadaran sebagai suatu kelompok yang diperkuat oleh ritus atau kegiatan keagamaan yang melibatkan semua warga agama. Dengan ritus seperti itu, agama mampu menyatukan semua warganya yang berbeda latar belakang. Selain itu, agama juga diharapkan dapat menjadi motivasi yang kuat. Agamaagama itu merupakan pandangan dunia (comprehensive worldview), demikian Habermas, bukan sekedar sistem nilai. Karena itu dalam agama ditemukan isi kognitif dan kekuatan motivasi bersama sebagai kelompok yang tidak ada dalam pandangan dunia yang profan. ${ }^{20}$ Dengan pandangannya itu Habermas sebenarnya ingin menjelaskan bahwa filsafat tidak perlu "terlalu percaya diri" seolah-olah ia sudah mengetahui dahulu apa yang menjadi inti dari tadisi-tradisi agama. Sebaliknya, adanya sikap terbuka untuk saling belajar merupakan sesuatu yang dituntut dari kedua belah pihak. Prinsip saling belajar dari warga sekular ini sejalan dengan pemikiran pasca-metafisik Habermas sendiri.

Selain tetap bersifat agnostik, rasio sekular post-metafisik perlu terbuka untuk belajar dari tadisi-tradisi keagamaan. Menurut Habermas, hal yang penting dari pemikiran pasca-metafisik adalah sikap menahan diri untuk membuat pernyataan ontologis atas sesuatu; tidak bersifat reduksionis. ${ }^{21}$ Baik agama maupun filsafat, perlu mengenal

19 A. Sunarko, Teologi Kontekstual (Yogyakarta: Kanisius, 2016), hlm. 199

${ }^{20}$ Ibid., hlm.200

${ }^{21}$ Jurgen Habermas, Between Naturalism and Religion (Cambridge: Polity Press, 2008) hlm. 140 
keterbatasannya sekaligus terbuka untuk saling belajar. Bagi Habermas, filsafat pasca-metafisik dapat terbuka untuk belajar dari agama, apabila ia mengenal kembali geneaologinya, yakni kesadaran bahwa ia juga anak waris dari agama-agama dunia. Artinya, kecanggihan gagasan filsafat sebenarnya punya intervensi dari tradisi-tradisi keagamaan. Oleh karena itu, proses belajar dari kedua belah pihak perlu menonjol ke permukaan lagi.

\section{Pola Hubungan Kedua Belah Pihak}

Ada beberapa pola hubungan saling belajar yang ditawarkan oleh Habermas. Pertama, terkait dengan warga sekular ataupun mereka yang indeferen terhadap doktrin dan praktik keagamaan. Secara statistis, jumlah warga sekular memang makin meningkat lewat modernisasi dan karena itu dialog dengan agama menjadi keharusan. Sikap warga sekular yang menilai agama sebagai artefak pra-modern dan irasional membuat mereka tidak mampu belajar dari nilai-nilai keagamaan. Mereka terkurung dalam klaim kebenarannya sendiri tanpa melihat potensi kebenaran dari agama sehingga keduanya mencapai saling pengertian. Di dalam tahap matang pemikirannya, Habermas menolak asumsi perkembangan linear menuju modernitas yang di dalamnya agama lama kelamaan akan ditinggalkan masyarakat yang menjadi modern. Warga sekular perlu bersikap terbuka dan perlu melihat nilai kognitif dalam agama agar mereka bebas dari penjara ketidaktahuan. Warga sekuler dan warga agama harus bertemu dalam penggunaan akal budi mereka di mata umum. ${ }^{22}$ Tuntutan demikian tentu tidak dapat diandaikan begitu saja, tetapi perlu dipelajari agar warga sekular sadar akan pentingnya agama. Cara yang dapat ditempuh adalah dengan melihat sejarah. Bagi Habermas, rasio sekular sebenarnya dihasilkan dari proses belajar secara kritis dari nilai-nilai agama, tanpa kehilangan substansinya. Bahkan Habermas mengakui bahwa Teori Kritisnya mengandung motif Kristiani karena konsep tindakan komunikatif yang dikembangkannya berakar pada warisan agama Kristen tentang komunitas Gereja yang saling mengerti..23

22 Jurgen Habermas, "The Political; The Rational Meaning of a Questionable Inheritance of Political Theology", dalam Eduardo Mendieta dan Jonathan (ed.), The Power of Religion in The Public Sphere (Columbia: Columbia University Press, 2011), hlm. 26

${ }^{23}$ F. Budi Hardiman, Habermas tentang Masyarakat Post-sekular (Jakarta: tidak diterbitkan, 2017), hlm. 8 
Arogansi sekularisme yang menilai agama sebagai irasional perlu ditinggalkan.

Kedua, terkait hubungan di antara berbagai kelompok agama. Berbagai agama harus menerjemahkan bahasa teologis partikular mereka ke dalam ungkapan rasional yang dapat diterima secara publik. Ini tantangan bagi setiap agama. Di satu sisi, setiap agama dituntut untuk "melunakkan" posisi mereka di hadapan agama lain dan warga sekular. Di sisi lain, adaptasi itu juga tanpa merelatifkan inti dogmatis agama itu sendiri. Dalam ruang publik, setiap agama menentukan posisi epistemisnya untuk mencari bahasa bersama dari setiap isi dogmatisnya, misalnya masalah HAM dan keadilan. Konteks Indonesia, konsensus dasar seperti Pancasila merupakan wawasan politis yang dapat mendorong sikap epistemis itu. Dalam arti ini, meski tidak berciri prosedural seperti 'rasio komunikatif', melainkan substansial, Pancasila ikut mendasari praksis komunikasi dalam ruang publik kita. ${ }^{24}$ Ketiga, terkait hubungan agama ketika berhadapan dengan otoritas ilmu pengetahuan. Agama tidak perlu menjadi oposisi ilmu pengetahuan yang semakin canggih. Sebaliknya, agama perlu menemukan posisi epistemisnya dalam proses saling belajar dengan ilmu pengetahuan agar mencapai saling pengertian. Proses ini dapat dikatakan berhasil apabila hubungan antara isi dogmatis agamanya dengan pengetahuan sekular sedemikian rupa, sehingga tidak terjadi pertentangan antara hasil kemajuan ilmu pengetahuan yang terus canggih dengan pandangan iman mengenai hal yang bersangkutan..$^{25}$

\section{Peran Agama dalam Ruang Publik}

Perbincangan mengenai peran agama dalam ruang publik harus ditempatkan dalam kerangka negara hukum demokratis yang di dalamnya orang dari berbagai agama dan tidak beragama hidup. Di dalam negara hukum demokratis itulah orang yang memiliki bekal metafisik ringan maupun berat saling berjumpa satu sama lain. Berhadapan dengan pluralitas seperti itu, sikap kritis atas peran agama dalam ruang publik perlu dilacak dengan cermat. Ruang publik merupakan arena yang harus dapat diakses semua orang, termasuk

${ }^{24}$ Ibid., hlm. 7

25 A. Sunarko, "Ruang Publik dan Agama menurut Habermas" dalam F. Budi Hardiman (ed), Ruang Publik; Melacak "Partisipasi Demokratis" dari Polis sampai Cyberspace (Yogyakarta: Kanisius,2010), hlm. 235 
warga agama. Ruang publik menjadi arena diskursif warga negara. Ruang publik tidak dapat menjadi arena eksklusif kelompok tertentu. Sesuai definisinya, ruang publik tidak lain daripada hakikat kondisikondisi komunikasi yang dengannya sebuah formasi opini dan aspirasi diskursif sebuah publik yang terdiri dari para warga negara dapat berlangsung. ${ }^{26}$ Warga negara yang dimaksudkan di sini tentu saja juga mencakup warga agama. Warga agama juga berhak menyatakan opini mereka di ruang publik, karena gagasan warga agama dapat didiskusikan secara rasional sebagai yang berpotensi memiliki isi kognitif. Tradisi agama memiliki kekuatan spesial untuk mengartikulasikan isi moralitasnya. ${ }^{27}$

Pandangan Habermas ini tentu berbeda dengan pendirian John Rawls yang hanya merekomendasi argumen sekular baik pada tataran ruang publik formal (parlemen, dsb.) maupun pada tataran ruang publik informal yang bersumber pada dunia kehidupan dan masyarakat warga sendiri. Memang penting untuk dimengerti bahwa Habermas membedakan antara ruang publik formal (parlemen, dsb.) dengan ruang publik informal (lebenswelt). Dalam ruang publik formal, misalnya "senayan", segala aspirasi atau opini yang "berbau" religius harus dihapus. Opini yang berlaku hanyalah yang dimengerti oleh semua orang, baik yang beragama maupun tidak. Opini yang bercorak sekular dibutuhkan ruang publik formal. Hal tersebut berbeda dengan ruang publik informal. Yang dimaksudkan Habermas dengan peran agama dalam ruang publik sebenarnya merujuk pada ruang publik informal. Ia merupakan arena diskursif yang otonom yang berbeda dari negara dan pasar. Ia berciri otonom karena tidak hidup dari kekuasaan administratif maupun ekonomi kapitalistis, melainkan dari sumbernya sendiri. Ruang publik bersumber pada Lebenswelt. Ruang publik informal bukanlah institusi dan tidak dikuasai oleh kelompok tertentu, tetapi inklusif. Keadaan dapat diakses semua orang itu membuat ruang publik informal menjadi tidak tunggal, tetapi terdapat di mana-mana dengan jumlah orang tidak terbatas. Ruang publik informal itulah arena bagi warga agama untuk menyatakan gagasan religiusnya masing-masing.

Namun demikian, opini warga agama juga perlu tahu batas bahwa keyakinan religius mereka yang telah dikemas menjadi suatu

${ }^{26}$ F. Budi Hardiman, Demokrasi Deliberatif; Menimbang Negara Hukum dan Ruang Publik dalam Teori Diskursus Habermas (Yogyakarta: Kanisius, 2009), hlm. 134

${ }^{27}$ Jurnal of philosophi, 10 
opini tidak dipaksa menjadi peraturan atau dasar negara. Tidak ada satu tradisi pun (termasuk agama) yang mengakui ajarannya sebagai norma bagi semua pihak. ${ }^{28}$ Hasrat primordial agama yang ingin menjadikan ajarannya sebagai pedoman bernegara perlu ditanggalkan. Peran agama untuk menggalang solidaritas sosial dalam ruang publik dan memotivasi warga beriman untuk mematuhi konstitusi tidak ditolak, namun peran itu akan berbahaya dan berlebihan apabila berubah menjadi aspirasi politis untuk mengganti konstitusi dan sistem hukum dengan hukum agama tertentu. Politisasi agama seperti itu tidak hanya merugikan pluralisme, tetapi juga mencederai agama itu sendiri dari kepentingan politik. ${ }^{29}$ Meskipun Indonesia belum mengalami proses sekularisasi, apalagi post-sekularisasi, namun sikap tahu batas dari agama seperti yang dikatakan Habermas merupakan pelajaran penting bagi kelompok fundamentalis di Indonesia.

Akhirnya dari pihak negara, ia harus menjunjung tinggi asas netralitasnya berhadapan dengan pluralitas pandangan. Semua masyarakat warga, baik yang beragama maupun tidak, perlu sadar bahwa negara memiliki pegangannya sendiri dalam menentukan hal yang baik atau buruk. Negara hukum demokratis tidak dapat menjadi negara agama. Negara tidak didasarkan pada agama atau pandangan hidup tertentu sebagai hukumnya. Kekosongan yang ditinggalkan akibat sikap netral terhadap pandangan hidup dan agama itu harus diisi oleh undang-undang yang demokratis. Negara hukum demokratis harus mampu membaharui syarat-syarat normatifnya dari kekuatannya sendiri. ${ }^{30}$ Dengan demikian, sikap negara sendiri dalam berelasi dengan seluruh warga negara seperti neraca yang setimbang.

28 Nicholas Adams, Habermas and Theology (Cambridge: Cambridge University Press, 2006), hlm. 5

${ }^{29}$ F. Budi Hardiman, Demokrasi Deliberatif; Menimbang Negara Hukum dan Ruang Publik dalam Teori Diskursus Habermas (Yogyakarta: Kanisius, 2009), hlm. 162

30 Jurgen Habermas, “Basis Prapolitis Sebuah Negara Hukum Demokratis", dalam Paul Kleden dan A. Sunarko (ed.), Dialektika Sekularisasi; Diskusi Habermas-Ratzinger dan Tanggapan (Maumere: Lamalera, 2010), hlm. 2 


\section{Penutup}

Konsep Habermas tentang masyarakat postsekluar sebenarnya memberi sumbangan penting bagi negara Indonesia. Meskipun hingga sekarang Indonesia belum tersekularkan, apalagi mencapai tahap postsekular, namun isi konsepnya penting dan relevan untuk dipelajari. Alasannya terletak pada apa yang disebut oleh Habermas kondisi saling belajar di antara kelompok sosial dan agama. Sikap tahu batas dari setiap agama yang ditawarkan Habermas sangat membantu apabila negara kita merindukan toleransi dan kesejahteraan. Setiap agama perlu menumbuhkan sikap saling belajar sehingga kecendrungan primordial yang saling mengkafirkan dapat diatasi. Artinya, kebandelan warga agama yang mengklaim sebagai pemilik keselamatan berikut melenyapkan agama lain perlu dihilangkan. Sebaliknya, setiap agama dapat mencari bahasa bersama yang bersumber pada ajarannya masingmasing untuk memerangi permasalahan sosial yang ada, seperti masalah HAM atau perdagangan manusia. Sikap kritis seperti itu merupakan kerja sama yang baik dari pihak agama dalam bernegara, sekalipun negara tidak perlu menjadi milik agama tertentu. 
Redemptus B. Gora, Melacak Peran Agama dalam Ruang Publik

\section{DAFTAR PUSTAKA}

A.B. Menoh, Agama Dalam Ruang Publik; Hubungan Antara Agama dan Negara dalam Masyarakat Postsekuler Menurut Jurgen Habermas, Yogyakarta: Kanisius, 2015.

Adams, Nicholas. Habermas and Theology, Cambridge: Cambridge University Press, 2006.

Budi Hardiman, F. Demokrasi Deliberatif; Menimbang Negara Hukum dan Ruang Publik dalam Teori Diskursus Habermas, Yogyakarta: Kanisius, 2009.

Budi Hardiman, F. Kritik Ideologi; Menyingkap Pertautan Pengetahuan dan Kepentingan Bersama Jurgen Habermas, Yogyakarta: Kanisius, 2009.

Budi Hardiman, F. Seni Memahami, Yogyakarta: Kanisius, 2015.

Budi Hardiman, F. (ed), Ruang Publik; Melacak "Partisipasi Demokratis" dari Polis sampai Cyberspace, Yogyakarta: Kanisius, 2010.

Budi Hardiman, F. Habermas tentang Masyarakat Post-sekular, Jakarta: tidak diterbitkan, 2017

Habermas, Jurgen. Between Naturalism and Religion Cambridge: Polity Press, 2008.

Kleden, Paul Budi dan A Sunarko (ed.), Dialektika sekularisasi; Diskusi Habermas-Ratzinger dan Tanggapan, Maumere: Lamalera, 2010.

Mendieta, Eduardo dan Jonathan (ed.), The Power of Religion in The Public Sphere, Columbia: Columbia University Press, 2011.

Sunarko, A. Teologi Kontekstual, Yogyakarta: Kanisius, 2016. 